\title{
MESA and MELA
}

\author{
DAVID PARTINGTON
}

HOR THREE DECADES I have considered myself a scholar in Middle East-
ern studies employed as a professional librarian. During that time of intense application of effort at Princeton, then Michigan, and finally Harvard, I have noted and been disturbed by the seeming lack of attention paid by MESA as an organization to matters concerning Middle Eastern librarianship, including, of course, the development of library resources to support Middle Eastern area studies. I state this apparent fact not in anger but rather in puzzlement.

For many years I regarded myself as a strong supporter of the MESA establishment, having known many of the early officers personally and even having served as a member of the MESA board of directors-the only librarian in the entire lifetime of MESA to have been so honored.

The recorded MESA interests in Middle Eastern librarianship are very few. As early as 1967, in the earliest days of MESA, the board of directors set up a Committee on Research and Training, headed by Bill Schorger of Michigan. In April of 1968 Schorger sent a questionnaire to each MESA fellow inquiring "what needs to be done to improve library and archival resources for research and training in your field ... ?" A direct consequence of the information that developed was the creation in July 1968 of a Library Sub-Committee, headed first by the late Labib Zuwiyya Yamak (Harvard) and then the present writer. I convened an organizational meeting at the MESA meeting in Denver (November 1971), at which my colleagues decided to create an organization of libraries, because the American Library Association did not fill our special needs. The Middle East Librarians' Association (MELA) was formally instituted a year later at the MESA meeting in Binghamton (November 1972). MELA, therefore, can be considered the first specialized offshoot of MESA.

This parenthood was manifest in MELA's first project, a survey of Middle Eastern library collections that Schorger had suggested. Prepared by Middle East librarian James Pollock (Indiana) in the summer of 1973 , and always referred to as the "MESA survey," it was the first and last tangible trace of the relationship of the two organizations.

The only positive accomplishment of MESA itself as an organization in the broad area of Middle East librarianship has been its support of 
the "Near East National Union List" (NENUL). MESA, as the official sponsor of NENUL, institutionally cooperated with the Library of Congress in successfully seeking funding from NEH. (Money was also obtained from the Hariri Foundation and Mobil Oil.) This large project (mentioned by Michael Albin in MESA Bulletin 22.2 [December 1988] 181-186), was not only very expensive, but it dragged on for years while the Library of Congress created a database. Finally, in 1988 a one-volume catalogue of the letter "A" was issued; but today, with funds spent, NENUL is terminated.

What, you may ask, is NENUL? For many, many decades, major research libraries used to send a card for every title they catalogued to the Library of Congress. Most of those cards were fed into the truly stupendous project known as the National Union Catalog (NUC). Cards for Middle Eastern vernaculars, specifically Arabic, Turkish, and Persian, however, were only partially represented in the NUC. The NENUL project included all the cards for items in those three languages that were submitted by over two hundred libraries to the Library of Congress through the year 1978. The aforementioned " $\mathrm{A}$ " volume represents about 13 percent of those cards and includes about 14,000 entries (including cross-references!) beginning with "a". The first fruit of this monumental project has been reviewed so far only in the somewhat obscure Bulletin of the International Association of Orientalist Librarians (nos. 32-33, 1988). MESA and its fellows seem to have ignored NENUL, and it is unlikely that more than a handful of researchers knows of the existence of this splendid bibliographic reference work.

It is this sporadic attention to Middle Eastern library matters that puzzles me. Other area studies groups can point to longstanding and strong interest by faculty in the development of resources for research. Faculty members play prominent roles in their respective special library associations, especially in Great Britain's MELCOM. Why this lack of concern in MESA?

One would like to think that our libraries are so well stocked that scholars are content with existing levels of collection development and services; or, less likely, that the vast majority of MESA members do not need more than a few dictionaries and encyclopedias, and an assortment of secondary sources for their research. Perhaps this is true of some of the social scientists in MESA who must rely on field research, but certainly historians and literary scholars, philosophers and students of religion need access to well-developed collections.

It may be true as well that librarians and librarianship are generally held in low esteem by faculty members, and MESA, which is overwhelmingly a group of faculty members, unwittingly acts accordingly. In an academic environment librarians must be ranked at a lower prestige level than faculty. I certainly would not argue that librarians should be given faculty status, for the functions of each profession are not the same. It is not the 
function of our profession per se to expand intellectual frontiers. Librarianship is a service profession, and the essential function of librarianship in the educational process is to facilitate access to sources of information.

In terms of membership, the 1988 MESA Roster of Members lists 38 librarians, or about 2 percent of the total membership of about 2000. Only 38 , yet these librarians number more than the members of 19 other MESArecognized disciplines. In twenty-four years of MESA, only one librarian has sat on the board of directors, and not until 1988 has a librarian sat on the important nominating committee. MELA's membership roster lists 140 personal members, many of whom have highly developed language skills and area specialization. It is unfortunate that more of them have not been brought within the mainstream of MESA.

I think the most telling evidence to support my contention that MESA is inattentive to library matters is found in The Study of the Middle East: Research and Scholarship in the Humanities and the Social Sciences, the 1976 publication edited by Leonard Binder as a project of the Research and Training Committee of MESA (John Wiley \& Sons, New York) and purporting to be the state-of-the-art summation on Middle Eastern studies. It did not mention librarians, library science, or librarianship.

Binder's book devotes a chapter to each of ten major disciplines within MESA. Each section is well written by an outstanding scholar, yet not one of them deemed it necessary to talk about library collections, the training of bibliographers, the cost involved in building collections, the sources of printed books, and so on. However, I do not want to imply that books are not mentioned. In fact, major portions of some of the chapters can be read as sophisticated bibliographical essays. And all of the chapters have bibliographies appended to them that are still worth close attention. But the word "libraries" is hardly mentioned. For example, Richard Antoun (Anthropology) admits with candor (p. 189) that "significant research may now be undertaken on the basis of the secondary resources now available in university and other libraries." And Oleg Grabar (Art), perhaps because of his efforts to build collections at Michigan and at Harvard, pays more attention to resources than any of his fellow writers. Not only does he freely use the word "libraries" (pp. 247, 249, 250, 252, and again on 256), but he even speaks in one paragraph of archives or depositories whose "problems are ... lack of personnel, sporadic funds, and uncertain direction over long periods of time." In this brilliant essay Grabar sees a "profound problem" in the control of new materials in the twenty-five or so languages of Islamic art. He pinpoints "creation of repositories of documents" as one of four approaches to the needs and priorities of his field. Significantly, Grabar reveals (p. 260) that "several commentators [who had critiqued his chapter prior to publication] pointed out that this report deals too much with cataloging and gathering information and documents, at the expense 
of developing ideas and theories." Seyyed Hossein Nasr in "Philosophy" uses the word "libraries" (pp. 331, 334, 335) and calls in passing for the fuller cataloguing of manuscript collections. He also sees the need for a center where all the primary and secondary sources and microfilms can be assembled (p. 341). This sounds like a library to me, but the "L" word is not used. "Political Science" completely avoids it. Gernot Windfuhr says in his magnificent survey of "Linguistics" (p. 381) that a "library of tapes" should be built up as a concomitant of dialect studies. Most amazingly, the fine essays on Arabic, Persian, and Turkish literatures do not mention the word "libraries," nor does Georges Sabagh's "Sociology." However, Sabagh does lament a lack of bibliographies. The final essay, "Economics" by John Simmons, skirts curiously around the issue of libraries as centers for resources. He never mentions the word but refers often to "collections of data." He hopes to avoid duplication in data collections and suggests that the responsibility for collecting and cataloguing data be shared.

As one who seeks no further recognition in life than to be known as an area studies librarian, I have always wondered why Binder's "state of the art" was seemingly blind to the work to which I devote myself along with some two dozen colleagues in research libraries around the country. Surely the annual budget for my department at Harvard exceeds the budgets of many academic departments in which teaching on the Middle East occurs. And surely, library resources are the foundation of every scholar's work. Do not the various centers at academic institutions boast about their library resources? Does not each center in its competitive application for federal funds always stress (and sometimes grossly exaggerate) the size of its book collection and emphasize how much money it doles out for library support? Why were Binder \& Co. so blind?

The history of the Middle East Microform Project (MEMP) provides another demonstration of low concern by MESA for library resources. When I became the first chairperson of MEMP I wrote a letter to all the directors listed in the $1987 \mathrm{MESA}$ directory of programs to ask their libraries to join MEMP. I sent a similar letter to the directors of libraries at institutions known to have Middle Eastern programs. None of the center directors deigned to reply except one or two personal friends; all the librarians answered. The stunning silence from the faculty convinced me that something is lacking in their outlook-namely, concern for the overall development of resources for Middle Eastern studies in this country.

Perhaps one reason for this lack of concern may be the success of what we librarians refer to as the PL- 480 program. So successful has this Library of Congress-run program been in providing Arabic books from Lebanon and Egypt (and books in other languages from Pakistan and India) to some twenty-five or so major American research libraries, that it is understandable for scholars to assume everything is OK in the library. This is far 
from true. For one thing, reliance on PL- 480 acquisition priorities results in building up twenty-five identical collections. Second, although hundreds of thousands of books have been transferred from Levantine shores to North America in the most massive transference of intellectual material ever to occur, these materials represent the publishing output of only a portion of the Arab and Islamic worlds. At this very moment, when vast areas of the Soviet Union are moving towards greater autonomy and perhaps independence, who is collecting vernacular publications of the indigenous peoples of Central Asia? Or, let's say, of the Turcomans and Kurds of Iraq? A common complaint of reviewers of books on the Kazakhs and other Turkic nations of Central Asia is that they are written solely from Russian sources. In my estimation, it is incumbent upon scholars and librarians alike to enter into immediate cooperative planning for an expansion of library resources to support the needs of researchers for the next half century. The Turkiclanguage speakers of Inner Asia, of Singkiang Province, as well as those who speak Pashto or Baluchi, inevitably will assume greater importance in the political sphere from now on. If a justification for area studies is that they promote the national understanding of critical areas, then planning must commence to build the research resources upon which new area studies are based. While some individual efforts in this direction have occurred, the magnitude of the task cries out for a cooperative initiative by MESA and other responsible bodies.

The final "evidence" that I wish to adduce in support of my contention that MESA neglects library development is the lack of visible reaction to the 1984 publication funded by the Department of Defense and titled Beyond Growth: The Next Stage in Language and Area Studies, written by Richard Lambert and others, and issued by the Association of American Universities. It is considered the most important study ever done on area studies in the United States, yet, so far as I can ascertain, no Middle Eastern scholar has reviewed it. ${ }^{1}$ What makes this work significant for the present discussion and highly worthy of MESA's focused attention is the amount of space allotted to library problems. Indeed, Lambert devotes an entire chapter to "Library and Information Resources," and he treats us to specific recommendations, which I here summarize and/or paraphrase:

1 Reviews have been published by a proponent of international education in the Journal of Asia Studies 44.3 (May 1985), by a scholar of Greek linguistics in the Modern Language Journal 69 (Autumn 1985), and by a librarian in MELA Notes. Dale L. Lange's review, "The Nature and Direction of Recent Proposals and Recommendations for Foreign Language Education: A Response" in the Modern Language Journal 71 (1987) 240-249, fears that Lambert's proposals will bring government control into academic language programs; and Adam Przeworski's review, titled "The Lambert Report," which appeared in $P S$ [Political Science] (Winter 1986) 78-83, provides a strongly worded indictment of Lambert's assumptions, conclusions, and recommendations in the political science sphere. 
1. Review the possibilities of developing mutual support and interface between academic and government library and information storage systems;

2. Train area studies librarians in information technologies;

3. Study library cataloguing backlogs to determine the extent of the problems and the best method to overcome them;

4. Explore the problems of acquisitions related to the area and draw up collective plans for ensuring the flow of materials;

5. Conduct, within the library system, a major review of problems within area-related collections from the perspectives of the universities and general librarians, as well as the specialists;

6. Participate actively in the ongoing efforts of the national library networks to develop collaboration in the development of collections and create a special task force to engage in such planning;

7. Enable national library networks to adapt indigenous language scripts;

8. Study the feasibility of including foreign databases in U.S. library networks;

9. Plan for preservation of area collections; and

10. Form a national body to monitor problems and coordinate area-specific collections.

If I am correct in ascribing to MESA an inattentiveness to library matters, and especially to collection development, I can also see that we librarians bear some of the blame. After all, cooperation is a two-way street--even between a pedestrian and a Mack truck. In partial explanation of our failure to move MESA into action is the indubitable fact that librarianship for the past two decades has been undergoing unsettling changes that have caused many of us to be preoccupied with internal functional processes to the exclusion of wider responsibilities. Overall, the necessity to automate library operations which has hit American libraries during the past two decades-decades of declining affluence - put into effect changes that will have long-range consequences on the ability of subject specialists to survive. In general terms, the attention of high-level librarians-I mean directors with the ability and the position to interact with local faculty and with national library and scholarly organizations-has not been directed to increasing our coverage of foreign area studies but rather to the installation of extremely costly systems, to programs of shared cataloguing, networks, and, now in the 1990s, to very expensive, labor-intensive (and hopeless?) preservation activities.

These activities reduce the funds available for collection development and for the nurturing of area specialists who could build collections intelligently and provide special reference service to faculty and students. Also, the national library organizations, such as ALA, ARL, CLR, CRL-also NEH and ACLS-through which top-level librarians function, have not been seized with the desire to expand collections, but rather they have 
favored programs to improve management, to facilitate access to what has already been collected, to share cataloguing and research resources, to develope systems for "information management," and now to preserve the old, constantly deteriorating nineteenth-century acidic paper book and serial stock. Current library literature proclaims that preservation is the librarians' issue for the next decade, but for me the real and continuing issue is the development of library collections for area studies in advance of faculty demands for them.

The problem for MESA-related library development is in part that we middle-level subject specialists do not have political power in libraries. Did I say middle-level? Some of my colleagues upon whom depend the selection and cataloguing of important collections operate as a sub-group in a general cataloguing department run by managers who have no conception of the intellectual processes of humanities or social science research and no idea that foreign area research is connected with national priorities. Librarians at my level do not influence institutional priorities. Our concerns-to serve the research needs of area specialists-play but minor roles on the internal library stage: we must have help from the wings. And that help ought to come from the nationally established organization of scholars known as MESA, because in no small measure the future of Middle Eastern studies in the twenty-first century depends on the development of library resources in this last decade of the twentieth.

I have no program to effect a nation-wide improvement in resources for research, but I first suggest that a greater appreciation and utilization by MESA as an organization of the talents of librarians would be beneficial to the future of Middle Eastern studies. A step in that direction would be to include a panel in the annual MESA conference on the topic of resources for research, with participation by faculty/researchers and librarians/bibliographers. Second, the recommendations of Lambert \& Co. in Beyond Growth deserve and must receive concentrated attention from scholars, administrators, national-level educators, and specialist librarians - and from MESA. Towards that end, I shall attempt to organize a workshop or conference of librarians to address the blanket theme of "Middle Eastern Studies and Library Resources." The conference will first specify directions that current Middle Eastern research is taking, and then take up the main purpose, which is to examine the ability of our present library and information systems to fill future research needs. Many library problems related to collection development need to be examined, clarified, and explained. The increase in factual information, in book production, in new frontiers of research, in new ways of looking at old problems as well as recording, accessing, and utilizing information-all this calls for a cooperative examination of mutually engaging problems by area specialists and the librarians who serve them.

Harvard College Library 


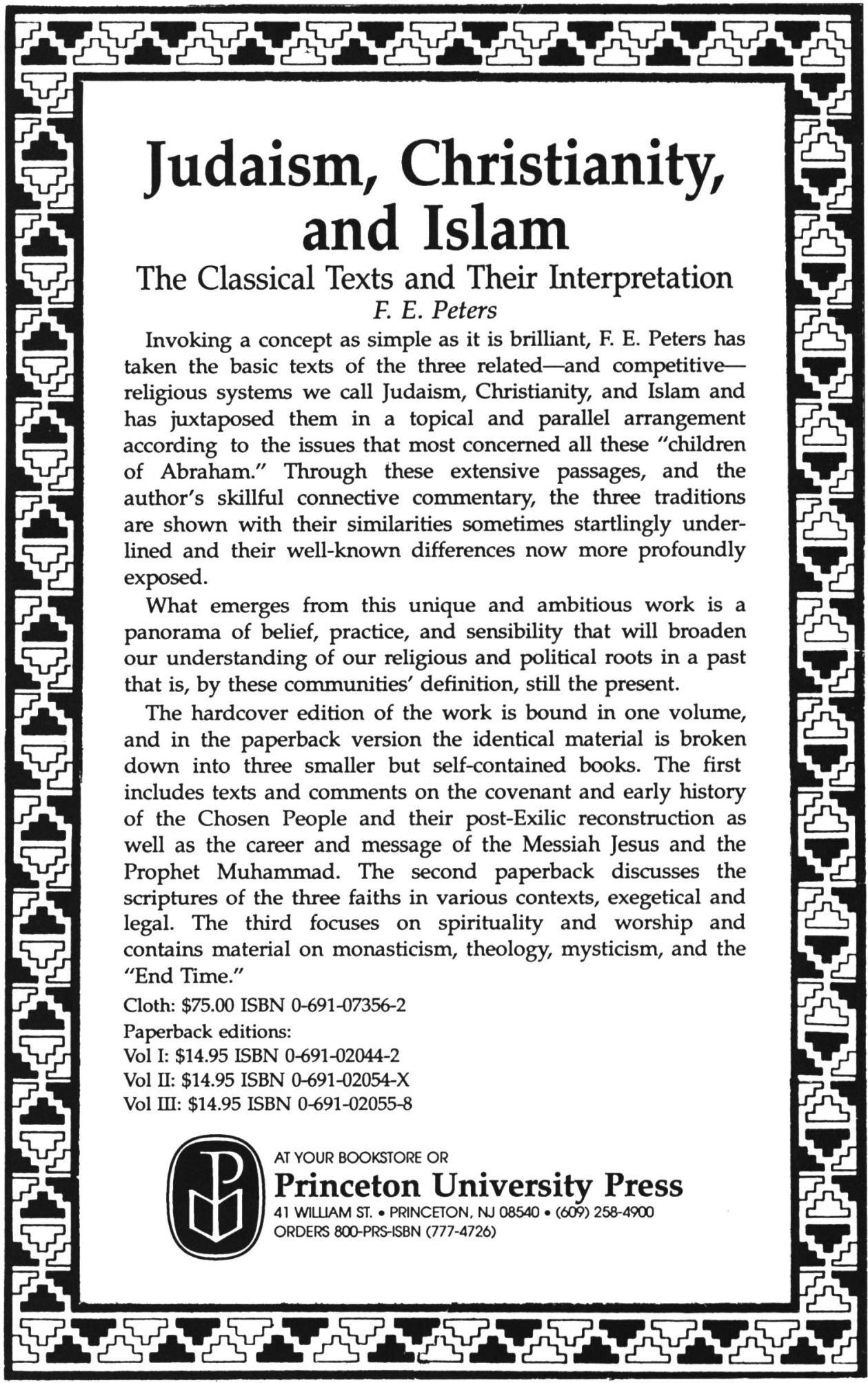

